Proceedings of the Annual Conference of the Agricultural Extension Society of Nigeria

Number: Twenty-Fifth Annual Conference

Theme: Enhancing the Role of Public and Private Extension in Soil Conservation and

Agricultural Productivity

Date: 28-29, July 2020

Venue: Usmanu Danfodiyo University, Sokoto, Nigeria

ISSN: 1595 - 1421.http://aesonnigeria.org/ConfProc . Email: editorinchief@aesonnigeria.org

\title{
Usage of Maize Storage Technologies for Postharvest Loss Prevention in Oke- Ogun/Saki Area of Oyo State, Nigeria \\ https://dx.doi.org/10.4314/jae.v25i1.2S
}

\section{Olusola B. Benson}

Department of Research Outreach, Nigerian Stored Products Research Institute (NSPRI), Yaba, Lagos, Nigeria. Email: bensonbrown24@gmail.com, Phone: 08054866174 (Corresponding author. E-mail: bensonbrown24@gmail.com)

\section{Adewale A. Afolabi}

Department of Durable Crops, Nigerian Stored Products Research Institute (NSPRI), Ilorin, Kwara State. Email:whale05us@yahoo.com, Phone: 08087777708

\section{Ajibade O. Ajayi}

Department of Research Outreach, Nigerian Stored Products Research Institute (NSPRI), Yaba, Lagos, Nigeria. Email: ajayibaderich@gmail.com, Phone: 08066671908

\section{Temitope S. Taiwo}

Department of Durable Crops, Nigerian Stored Products Research Institute (NSPRI), Yaba, Lagos, Nigeria. Email: temitopeolalere59@yahoo.com, Phone: 08064898393

\section{Oluwabunmi M. Omotuyi}

Department of Research Outreach, Nigerian Stored Products Research Institute (NSPRI), Yaba, Lagos, Nigeria. Email: bunmiolubowale@gmail.com, Phone: 07036765464

\section{Egobude U. Okonkwo}

Department of Durable Crops, Nigerian Stored Products Research Institute (NSPRI), Yaba, Lagos, Nigeria. Email: egobude1@gmail.com, Phone: 08027146330

\begin{abstract}
This study assessed the usage of traditional and improved maize storage technologies by farmers in Saki/Oke-Ogun area of Oyo State. The study was conducted from April-July, 2019; using a validated structured questionnaire for data collection. A multi-stage sampling technique was adopted to draw a sample of 191 maize farmers. Grain storage technologies usage frequency was measured on a four-point Likert-type numerical scale 4-1 as regularly, occasionally, seldom, and never respectively. Descriptive analysis of collected data revealed regular usage of both raffia woven basket (98.9\%) and traditional crib (96.1\%) by respondents. Sampled maize farmers overwhelmingly indicated non-usage of rhombus (98.0\%) to store their produce; with a substantial number (88.2\%) rarely using containers. Further analysis shows maize farmers used improved crib regularly (76.5\%). Inert atmosphere silo (80.4\%), conventional silo (76.5\%), purdue improved crop storage $(90.2 \%)$ and zerofly ${ }^{\mathrm{TM}}$ (65.4\%) bags were never used to store maize by farmers. Chisquare $\left(\chi^{2}\right)$ analysis revealed significant $(p \leq 0.05)$ associations between technology
\end{abstract}




\section{Proceedings of the Annual Conference of the Agricultural Extension Society of Nigeria}

Number: Twenty-Fifth Annual Conference

Theme: Enhancing the Role of Public and Private Extension in Soil Conservation and Agricultural Productivity

Date: 28-29, July 2020

Venue: Usmanu Danfodiyo University, Sokoto, Nigeria

ISSN: 1595 - 1421.http://aesonnigeria.org/ConfProc . Email: editorinchief@aesonnigeria.org

usage and socioeconomic characteristics of maize farmers. The cost and bulk storage nature of improved storage technology could be traced to its never used; while awareness is also very low on the use of those cost effective bagged technologies.

Keywords: Storage usage, traditional grain technology.

\section{Introduction}

Grain storage technologies in some literatures were also regarded as techniques, methods or structures. Nigerian Stored Products Research Institute (NSPRI, 1988) and Food and Agricultural Organisation, (FAO, 1994) classified storage technologies into three categories namely: traditional grain storage technologies (TGST); improved grain storage technologies (IGST) and modern centralized grain storage technologies (MCGST).

On-farm and off-farm TGST are so regarded because of its age long practice by farmers and are mostly made of unrefined local materials. They are usually small sized and often used for short term storage, which includes raffia baskets, cribs, rhombus, platforms/shelf, open field, roof, fireplace, storage bags, earthen pots and gourds (Adesida, 2008; Picard and Proctor, 1994; NSPRI, 1988). Improved grain storage technologies are products of innovations, storage ingenuity and/or efforts made by certain individuals, local and international non-governmental organizations or research institutions at improving the traditional structures which were subsequently patented as technologies. They are often used for medium term storage, classified into on-farm, domestic and commercial storage technologies. Examples are ventilated metal crib, polyethylene/jute bags, metal/brick bins, and hermetic storage technology which include zerofly ${ }^{\mathrm{TM}}$ bag, purdue improved crop storage (PICS) bag and plastic or metal drum with screw caps. Modern centralized grain storage technologies which includes silos and warehouses were developed to store grains for long time purpose; usually gigantic structures with sophisticated operations used for commercial storage of grains or strategic grains reserve (Udoh et al., 2000). Farmers use these technologies to store excess grains produced during production season which are released into markets during lean/low production season, this is done to balance demand-supply chain to even-out price fluctuation of the commodities in markets places. Some are also used to store seeds for the next planting season. It's relevant therefore to assess the frequency of usage of these technologies by maize farmers in the study area for storage of maize and other grains.

\section{Methodology}

Oyo State is one of the states in the South-west geopolitical zone of Nigeria which lies between longitude $2^{0} 4^{1}$ and $4^{0} 3^{1}$ East and $7^{0} 2^{1}$ and $9^{0} 2^{1}$ North (fig. 1). According to National Population Commission (2006), Oyo State has a population of 5,591,589 people with 33 local government areas (LGAs) divided into four agricultural zones 


\section{Proceedings of the Annual Conference of the Agricultural Extension Society of Nigeria \\ Number: Twenty-Fifth Annual Conference}

Theme: Enhancing the Role of Public and Private Extension in Soil Conservation and Agricultural Productivity

Date: 28-29, July 2020

Venue: Usmanu Danfodiyo University, Sokoto, Nigeria

ISSN: 1595 - 1421.http://aesonnigeria.org/ConfProc . Email: editorinchief@aesonnigeria.org

(Ogbomoso zone, Ibadan/lbarapa zone, Oyo zone and Oke-Ogun/Saki zone). The indigenes are the Yoruba's with appreciable proportions of other Nigerians and Nationals of neighbouring West Africa countries like Benin Republic, Ghana and Republic of Togo. Majority of the people engage in farming and trading with appreciable proportion in the civil service. The climatic conditions of the State encourage the cultivation of cash crops such as cashew, citrus, cocoa, and kolanut, arable crops like maize, cassava, and yam performs well on the fertile soil.

The list of blocks, cells, and all the registered names (totaled 1873) and contact addresses of maize farmers in Oke-Ogun/Saki Agricultural zone were obtained from Oyo State Agricultural Development Programmes (OYSADEP). A multistage sampling technique which involves proportionate selection of $50 \%$ of the component blocks that made up each zone was done at random; followed by proportionate selection of $20 \%$ of component cells that made up each selected block, done also at random, and finally, proportionate selection of $20 \%$ of maize farmers in each selected cell (Table 1). Thus, a total of 191 maize farmers were selected for this study.

Table 1: Sampling of maize farmers in Oke-Ogun/Saki Agricultural Zone of Oyo State

\begin{tabular}{|c|c|c|c|c|c|c|}
\hline Zone & Blocks & $\begin{array}{l}\text { No of maize } \\
\text { farmers }\end{array}$ & $\begin{array}{l}50 \% \text { of } \\
\text { Blocks }\end{array}$ & $\begin{array}{l}20 \% \text { of cells in } \\
\text { each Block }\end{array}$ & $\begin{array}{l}20 \% \text { of maize } \\
\text { farmers }\end{array}$ & $\begin{array}{l}\text { Total no of farmers } \\
\text { for sampling }\end{array}$ \\
\hline \multirow[t]{10}{*}{$\begin{array}{l}\text { Oke- } \\
\text { Ogun/Saki }\end{array}$} & Saki-West & 260 & Saki-East & $\begin{array}{l}\text { Aba-Isehin } \\
\text { Aba-Ogbomoso }\end{array}$ & 52 & 52 \\
\hline & Irepo & 250 & & & & \\
\hline & Olorunsogo & 224 & & & & \\
\hline & Saki-East & 202 & Iwajowa & Igbo-Eleeru & 40 & 40 \\
\hline & & & & Aba-Okeho & & \\
\hline & Iwajowa & 200 & & & & \\
\hline & Kajola & 244 & & & & \\
\hline & Orelope & 245 & Kajola & Ilero, Ilua & 49 & 49 \\
\hline & Atisbo & 248 & & & & \\
\hline & & & Atisbo & Tede, Ago-Are & 50 & 50 \\
\hline Total & & 1873 & & & 191 & 191 \\
\hline
\end{tabular}

Adapted from Sangotegbe et.al, (2012)

To test the research model, a questionnaire survey was used to gather research data. The data collection instrument contained self-generated lists of traditional and improved grain storage technologies; which required respondents to indicate the ones in-use, where multiple responses were allowed. Frequency of usage of listed technologies was measured using a four-point Likert-type numerical scale 4-1 as 


\section{Proceedings of the Annual Conference of the Agricultural Extension Society of Nigeria}

Number: Twenty-Fifth Annual Conference

Theme: Enhancing the Role of Public and Private Extension in Soil Conservation and Agricultural Productivity

Date: 28-29, July 2020

Venue: Usmanu Danfodiyo University, Sokoto, Nigeria

ISSN: 1595 - 1421.http://aesonnigeria.org/ConfProc . Email: editorinchief@aesonnigeria.org

regularly, occasionally, rarely and never respectively. Content validity of the data collection instrument was adapted from previous literature (Del Siege, 2010) and facial validity was carried out by experts, items found ambiguous were removed.

IBM-SPSS statistics 20.0 was used for data analysis. Data collected were subjected to descriptive statistical analysis. Inferential statistical tool such as Chi-square was used to test the association between storage technologies usage and socioeconomic characteristics of the farmers.

\section{Results and Discussion}

\section{Frequency of Use of Grain Storage Technologies}

Table 2 reveals regular usage of both "raffia woven basket" (98.9\%) and "traditional crib" (96.1\%); this is in line with Adebisi et. al., (2015) who reported regular usage of both technologies in certain parts of Oyo state different from the present area of this study. Rhombus was never used by $98.0 \%$ of the sampled respondents just as eighty-five percent of sampled respondents indicate they never used "underground pit" to store their grain; Adesina et al., (2019); Adejumon and Raji, (2007); and Jelle, (2003) all affirmed the use of these technologies mainly in the dry tropics of Northern Nigeria. Eighty-eight percent of the sampled respondents rarely use "containers" in the traditional storage technology category; this is a priori expectation in the sense that storage in containers is a form of domestic and off-farm techniques often used mainly for storage of shelled grains at homes (Nigerian Stored Products Research Institute, 1982). Gourds are the hard, dried outside cases of certain fruits or vegetable, nearly $83 \%$ of sampled respondents indicated they never used these small capacity containers for storage of their produce, this is line with Picard and Proctor (1994) and NSPRI (1988) which asserts the predominant use of gouts in some villages in very few states of Northern Nigeria.

Table 2 further shows that $76.5 \%$ of maize farmers in the study area use "improved maize crib" regularly to store their maize. Inert atmosphere silo and conventional silo were never used to store maize by $80.4 \%$ and $76.5 \%$ of sampled respondents respectively; this may not be too surprising as these technologies were developed for bulk and commercial storage of grains. Also, PICS and zerofly ${ }^{\mathrm{TM}}$ bags were never used to store maize by $90.2 \%$ and $65.4 \%$ of sampled farmers respectively; despite that bags technologies are very cost effective, the poor usage is a clear indication of little or no awareness created on these technologies for storage of maize and other grains by farmers across the study locations. Nwaubani, et.al; (2020) reported the use of PICS and zerofly ${ }^{\mathrm{TM}}$ bags in markets storehouses within lbadan metropolis by traders and grain merchants for insect-pest management. In a similar vein, the rare $(62.7 \%)$ usage of "warehouse bagged storage" could be attributed to low level of awareness and adoption of electronic warehouse receipt system (e-WRS) as a way of reducing storage loss (Benson et.al, 2019) in certain parts of the study area. 


\section{Proceedings of the Annual Conference of the Agricultural Extension Society of Nigeria \\ Number: Twenty-Fifth Annual Conference}

Theme: Enhancing the Role of Public and Private Extension in Soil Conservation and Agricultural Productivity

Date: 28-29, July 2020

Venue: Usmanu Danfodiyo University, Sokoto, Nigeria

ISSN: 1595 - 1421.http://aesonnigeria.org/ConfProc . Email: editorinchief@aesonnigeria.org

Table 2: Usage of traditional and improved grain storage technologies

\begin{tabular}{|c|c|c|c|c|c|c|c|}
\hline $\begin{array}{l}\text { Storage } \\
\text { Technology }\end{array}$ & $\begin{array}{l}\text { Reg } \\
\%\end{array}$ & $\begin{array}{l}\text { Occa } \\
\%\end{array}$ & $\begin{array}{l}\text { Rarely } \\
\%\end{array}$ & $\begin{array}{l}\text { Never } \\
\%\end{array}$ & $\begin{array}{l}\text { Wtd } \\
\text { Score }\end{array}$ & $\begin{array}{l}\text { Wtd } \\
\text { Mean }\end{array}$ & Ranking \\
\hline Traditional & & & & & & & \\
\hline Raffia woven basket & 98.9 & 1.1 & Nil & Nil & 762 & 3.99 & $1^{\text {st }}$ \\
\hline Traditional maize crib & 96.1 & 2.0 & 2.0 & Nil & 744 & 3.89 & 2nd \\
\hline Roof Storage & 23.6 & 17.6 & 35.3 & 23.5 & 461 & 2.41 & $3 r d$ \\
\hline Hang-Over fire & 21.6 & 19.6 & 33.3 & 25.5 & 452 & 2.37 & 4 th \\
\hline Earthen Pots & 2.0 & 27.5 & 64.7 & 5.9 & 431 & 2.26 & 5 th \\
\hline Containers & Nil & 5.9 & 88.2 & 5.9 & 382 & 2.00 & 6th \\
\hline Gout & 2.0 & 2.0 & 13.7 & 82.4 & 241 & 1.26 & 7 th \\
\hline Underground pit & Nil & Nil & 15.7 & 84.3 & 221 & 1.16 & 8th \\
\hline $\begin{array}{l}\text { Rhombus } \\
\text { Improved }\end{array}$ & Nil & 2.0 & Nil & 98.0 & 189 & 0.99 & $9^{\text {th }}$ \\
\hline Improved maize crib & 77.4 & 22.6 & $\mathrm{Nil}$ & Nil & 721 & 3.77 & $1^{\text {st }}$ \\
\hline Hermetic drum & Nil & 21.6 & 58.8 & 19.6 & 385 & 2.01 & $2^{\text {nd }}$ \\
\hline $\begin{array}{l}\text { Warehouse bagged } \\
\text { storage }\end{array}$ & Nil & 6.8 & 64.4 & 28.8 & 340 & 1.78 & $3 r d$ \\
\hline Conventional silo & Nil & Nil & 23.5 & 76.4 & 236 & 1.24 & $4^{\text {th }}$ \\
\hline Inert atmosphere silo & Nil & Nil & 19.6 & 80.4 & 228 & 1.19 & $5^{\text {th }}$ \\
\hline ZeroFly Bags $^{\mathrm{TM}}$ & 3.1 & 11.0 & 20.4 & 65.4 & 290 & 1.51 & $6^{\text {th }}$ \\
\hline $\begin{array}{l}\text { Purdue Pmproved } \\
\text { Crop Storage (PICS) } \\
\text { Bag }\end{array}$ & Nil & 2.0 & 7.8 & 90.2 & 214 & 1.12 & $7^{\text {th }}$ \\
\hline
\end{tabular}

Source: Field Survey, 2019. Reg = Regularly, Occa= Occasionally, Wtd Mean= Weighted Mean

\section{Associations between Storage Technology Usage and Socio-Economic Characteristics of Maize Farmers}

Tables 3-6 show that storage technologies in both traditional and improved categories which includes hang-over fire, pots, roof storage, inert atmosphere silo, hermetic plastic/metal drum, conventional silo, improved crib, warehouse bagged storage, shows significant associations with the years of storage experience of maize farmers (Table 3). This is a strong indication that the experienced gained over the years using these technologies could have exposed them to proper usage thereby harnessing the storage benefits therein; Ainembabazi and Mugisha (2014) found a relationship between adoption-usage and years of experience with agricultural technologies in maize and other crops. Analysis of storage technologies usage in relation to the educational status of maize farmer (Table 4) reveals to a large extent that, educational status of farmers played a vital role in usage of these technologies with relationships showing high level of significance $(p=0.000)$, most especially in the improved technologies category. This implies that the educational status of the respondents enabled them to utilize the benefits these technologies presents; Adebisi et al., (2015) recorded similar observation in their study.

Socio-economic characteristic of respondents such as household size (Table 5) and annual income (Table 6) were significantly associated with storage technology usage $(p \leq 0.05)$. Household size of farm family shows availability of manual labour; 


\section{Proceedings of the Annual Conference of the Agricultural Extension Society of Nigeria}

Number: Twenty-Fifth Annual Conference

Theme: Enhancing the Role of Public and Private Extension in Soil Conservation and Agricultural Productivity

Date: 28-29, July 2020

Venue: Usmanu Danfodiyo University, Sokoto, Nigeria

ISSN: 1595 - 1421.http://aesonnigeria.org/ConfProc . Email: editorinchief@aesonnigeria.org

consequently, large household size could increase production output leading to availability of more farm produce for consumption, sales as well as for storage purposes, this supports Urgessa (2015) that household size and others are the most significant variables that affects agricultural productivity which could in- turn affect storage.

Data in Tables 3, 4, and 6 show that there were no significant associations $(p \geq 0.05)$ between variables such as years of storage experience; educational status; and annual income of the respondents, and usage of Raffia Palm Basket storage technology. This could be due to the fact that the technology is made from indigenous/native knowledge of weaving with hands, learned from family members, which has become a tradition in consonance with Benson, (2020) who found out that tradition and family members are the main sources of information and training on traditional technologies. Similarly, usage of bags storage technologies (PICS and ZeroFly) and years of storage experience of the respondents are not significantly associated $(p \geq 0.05)$, the implication of this is that farmers gained little experience due to poor usage; a consequence of low awareness about the technologies.

Table 3: Association between the storage technologies used and years of storage experience

\begin{tabular}{llll}
\hline \multirow{2}{*}{ Variables } & Years of Storage Experience & \\
\cline { 2 - 4 } & $\chi^{2}$-value & Df & $\begin{array}{l}\text { Contingency } \\
\text { Coefficient }\end{array}$ \\
\hline Inert atmosphere silo & $33.213^{*}$ & 15 & 0.384 \\
Hermetic drum & $112.567^{*}$ & 30 & 0.608 \\
Conventional silo & $36.757^{*}$ & 15 & 0.401 \\
Improved maize crib & $49.580^{*}$ & 15 & 0.453 \\
Warehouse bagged & $137.661^{*}$ & 30 & 0.646 \\
PICS bags & 25.803 & 30 & 0.755 \\
ZeroFly bags & 18.002 & 21 & 0.674 \\
Raffia palm basket & 17.244 & 16 & 0.620 \\
Hang-over Fire & $190.292^{*}$ & 45 & 0.706 \\
Pots & $133.466^{*}$ & 34 & 0.640 \\
Roof storage & $198.726^{*}$ & 60 & 0.713 \\
Traditional Crib & 16.377 & 30 & 0.280 \\
\hline
\end{tabular}

${ }^{\star} \mathrm{P} \leq 0.05$. Source: Field Survey, 2019

Table 4: Association between the storage technologies used and educational status

\begin{tabular}{llll}
\hline \multirow{2}{*}{ Variables } & Educational status & & \\
\cline { 2 - 4 } & $\chi^{2}$-value & Df & $\begin{array}{l}\text { Contingency } \\
\text { Coefficient }\end{array}$ \\
\hline Inert atmosphere silo & 77.119 & 3 & 0.535 \\
Hermetic drum & 27.009 & 6 & 0.351 \\
Conventional silo & 57.534 & 3 & 0.480 \\
Improved maize crib & 12.554 & 3 & 0.248 \\
Warehouse bagged & 45.169 & 6 & 0.436 \\
PICS bags & 29.938 & 6 & 0.367 \\
ZeroFly bags & 23.342 & 4 & 0.246 \\
Raffia palm basket & 42.621 & 6 & 0.241 \\
Hang-over Fire & 206.272 & 9 & 0.720 \\
Pots & 85.378 & 9 & 0.555 \\
Roof storage & 26.616 & 5 & 0.728 \\
Traditional Crib & 26.948 & 6 & 0.351 \\
\hline *P 0 S Source: Field Survey $\mathbf{2 0 1 9}$ & &
\end{tabular}

${ }^{\star} \mathrm{P} \leq 0.05$. Source: Field Survey, 2019 
Proceedings of the Annual Conference of the Agricultural Extension Society of Nigeria

Number: Twenty-Fifth Annual Conference

Theme: Enhancing the Role of Public and Private Extension in Soil Conservation and Agricultural Productivity

Date: 28-29, July 2020

Venue: Usmanu Danfodiyo University, Sokoto, Nigeria

ISSN: 1595 - 1421.http://aesonnigeria.org/ConfProc . Email: editorinchief@aesonnigeria.org

Table 5: Association between the storage technologies used and household size

\begin{tabular}{llll}
\hline Variables & Household Size & & \\
\cline { 2 - 4 } & $\chi^{2}$-value & Df & $\begin{array}{l}\text { Contingency } \\
\text { Coefficient }\end{array}$ \\
\hline Inert atmosphere silo & 37.353 & 7 & 0.404 \\
Hermetic drum & 96.527 & 14 & 0.578 \\
Conventional silo & 44.684 & 7 & 0.435 \\
Improved maize crib & 75.501 & 7 & 0.531 \\
Warehouse bagged & 78.956 & 14 & 0.540 \\
PICS bags & 31.797 & 14 & 0.377 \\
ZeroFly bags & 31.342 & 14 & 0.374 \\
Raffia palm basket & 38.632 & 12 & 0.381 \\
Hang-over Fire & 167.079 & 21 & 0.682 \\
Pots & 113.021 & 21 & 0.608 \\
Roof storage & 184.598 & 28 & 0.700 \\
Traditional Crib & 76.205 & 14 & 0.533 \\
\hline
\end{tabular}

${ }^{*} \mathrm{P} \leq 0.05$. Source: Field Survey, 2019

Table 6: Association between the Storage Technologies used and annual income

\begin{tabular}{llll}
\hline \multirow{2}{*}{ Variables } & Annual Income & & \\
\cline { 2 - 4 } & $\chi^{2}$-value & Df & $\begin{array}{l}\text { Contingency } \\
\text { Coefficient }\end{array}$ \\
\hline Inert atmosphere silo & 48.822 & 9 & 0.450 \\
Hermetic drum & 69.556 & 18 & 0.516 \\
Conventional silo & 41.173 & 9 & 0.420 \\
Improved maize crib & 16.942 & 9 & 0.285 \\
Warehouse bagged & 77.314 & 18 & 0.536 \\
PICS bag & 214.927 & 18 & 0.727 \\
ZeroFly bags & 121.342 & 12 & 0.540 \\
Raffia palm basket & 101.774 & 22 & 0.365 \\
Hang-over Fire & 120.181 & 27 & 0.620 \\
Pots & 49.966 & 27 & 0.454 \\
Roof storage & 139.927 & 36 & 0.649 \\
Traditional Crib & 54.966 & 18 & 0.472 \\
\hline
\end{tabular}

${ }^{*} \mathrm{P} \leq 0.05$. Source: Field Survey, 2019

\section{Conclusion and Recommendations}

Maize storage technologies in the traditional category recorded good usage amongst the sampled respondents; this could be traced to the fact that usage knowledge was learned over time from family members. Maize farmers in the study area indicated poor usage of improved storage technologies consequence of cost of the technology, bulk storage nature and low level of awareness created for the cost effective ones. The socio-economic characteristics of maize farmers such as years of storage experience, their educational status, the size of their family household as well as the annual income accrued from their farming enterprise played vital roles in usage or otherwise of these technologies.

Bagged storage technologies (ZeroFly and PICS) are affordable and simple to use, there is the need for raising the level of awareness on the use of these cost effective bag technologies by extension agents, NSPRI and other relevant stakeholders. 


\section{Proceedings of the Annual Conference of the Agricultural Extension Society of Nigeria}

Number: Twenty-Fifth Annual Conference

Theme: Enhancing the Role of Public and Private Extension in Soil Conservation and Agricultural Productivity

Date: 28-29, July 2020

Venue: Usmanu Danfodiyo University, Sokoto, Nigeria

ISSN: 1595 - 1421.http://aesonnigeria.org/ConfProc . Email: editorinchief@aesonnigeria.org

\section{References}

Adebisi, G.L., Owolade, E.O. and Jatto, B.O. (2015): Assessment of the Use of Maize Storage Structures among Maize Farmers in Ido Local Government Area of Oyo State. . Open Access Library Journal, 2: e1882. http://dx.doi.org/10.4236/oalib.1101882

Adejumon, B. A. and Raji, A. O. (2007): Technical Appraisal of Grain Storage Systems in the Nigerian Sudan Savannah. Agricultural Engineering International: the CIGR Ejournal. Invited Overview No. 11. Vol. IX.

Adesida, A. (2008): On Farm Storage Structure in Nigeria. A paper presented at processing and storage unit seminar in Nigeria. April 12-18.

Adesina, J.M., Nameirakpam Bunindro, Dinabandhu Sahooand Yallappa, Rajashekar (2019): Traditional methods of food grains preservation and storage in Nigeria and India. Annals of Agricultural Sciences,Volume 64, Issue 2, Pages 196-205.

Ainembabazi, J. H. and Mugisha, J. (2014): The Role of Farming Experience on the Adoption of Agricultural Technologies: Evidence from Smallholder Farmers in Uganda. The Journal of Development Studies, 50:5, 666-679, DOI:10.1080/00220388.2013.874556

Ajah J. I and Nmadu J. N. (2012): Farmers' Perception of Problems Influencing Maize Storage In Abuja, Nigeria. Journal of Applied Agricultural Research 5(2): 89-94

Benson, O.B. (2020): Assessment of Efficiency of Traditional and Improved Maize Cribs Storage Technologies Adopted by Maize Farmers in Southwest, Nigeria. Unpublished Ph.D. thesis. Department of Agricultural Extension and Rural Development, Federal University of Agriculture Abeokuta, Nigeria.

Benson, O.B., Oose, O.M., Fapohunda, T.B., ljaware, O.A. (2019): Conceptualizing Warehouse Receipts System as a Viable Alternative for Postharvest Storage Loss Reduction Strategy in Grain by Small-Holders Farmers in Nigeria. Proceedings of the Farm Management Association of Nigeria, Pp 356-361.

Del Siege, (2010): Educational Research Basics, Nang School of Education-University of Connecticut

Food and Agricultural Organisatio (FAO), (1994): Grain storage techniques: Evolution and trends in developing countries. Edited by D.L. Proctor, FAO Consultant, FAO Agricultural Services Bulletin No. 109. Food and Agriculture Organization of the United Nations (FAO), Rome.

Ibitola O.R., Fasakin I.J., Popoola O.O., Olajide O.O. (2019): Determinants of Maize Framers' Productivity among Smallholder Farmers in Oyo State, Nigeria. Greener Journal of Agricultural Sciences Vol. 9(2), pp. 189-198, DOI Link: http://doi.org/10.15580/GJAS.2019.2.040219062

Jelle Hayma (2003). The storage of tropical agricultural products. (Ed.): Sara van Otterloo-Butler. Agrodok 31, Fourth edition: pg; 52. ISBN: 90-77073-60-4.

Ogunsumi, L. O., Okunlola, J.O., and Ewuola, S.O. (2010): Adoption pattern of farmers in Southwest, Nigeria: The case of maize and cassava farmers. Agriculture and Biology Journal of North America 1(4): 476-481. http://www.scihub.org/ABJNA

Picard, J. and Proctor, D.L. (1994): Storage at Farm/Village Level and in Warehouses (In) Grain storage techniques: Evolution and trends in developing countries (Ed) Proctor, D.L. FAO AGRICULTURAL SERVICES BULLETIN 109. $\operatorname{Pg} 1-23$. 
Proceedings of the Annual Conference of the Agricultural Extension Society of Nigeria

Number: Twenty-Fifth Annual Conference

Theme: Enhancing the Role of Public and Private Extension in Soil Conservation and Agricultural Productivity

Date: 28-29, July 2020

Venue: Usmanu Danfodiyo University, Sokoto, Nigeria

ISSN: 1595 - 1421.http://aesonnigeria.org/ConfProc . Email: editorinchief@aesonnigeria.org

National Population Commission (NPC), (2006): National Population Commission, 2006

Nigerian Stored Products Research Institute (NSPRI) (1988). 25th Annual Reports, 1989. Pg. 18-21.

Nigerian Stored Products Research Institute (NSPRI) (1982): Storing your Produce: Advisory Booklet No. 1. Maize.

Nwaubani, S.I., Otitodun, G.O., Ajao, S.K., Opit, G.P., Ala, A.A., Omobowale, M.O., Ogwumike, J.C., Abel, G.l., Ogundare, M.O., Braimah, J.A., Gbenga, B.S., Olenloa, A.E., Kolayemi, O.R., McNeill, S.G., Ileleji, K.E. (2020) 'Assessing efficacies of insect pest management methods for stored bagged maize preservation in storehouses located in Nigerian markets' Journal of Stored Products Research 86101566 https://doi.org/10.1016/.jspr.2019.101566

Udoh, J.M., Cardwell, K.F. and Ikotun, T. (2000): Storage structure and aflatoxin content of maize in 5 agro ecological Zones of Nigeria, Journal of Stored Products Research 36.2: 187- 201.

Urgessa Tessema (2015). The Determinants of Agricultural Productivity and Rural Household Income in Ethiopia, Ethiopian Journal of Economics Vol. XXIV No 2, October 